\title{
EXPLORATION OF ANIMALS EXPLOITATION IN FOOD, CLOTHES, ENTERTAINMENT AND TESTING INDUSTRIES, ITS IMPACT ON ECONOMY AND ECOLOGY
}

Akhmetov R.R. (Russian Federation) Email: Akhmetov332@scientifictext.ru

\author{
Akhmetov Radmir Rustemovich - Student, \\ PETROLEUM ENGINEERIND DEPARTMENT, \\ SAINT PETERSBURG MINING UNIVERSITY, \\ SAINT PETERSBURG
}

Abstract: this article investigates all spheres, where people exploit animals (food, clothes, vivisection, entertainment) to show the scope of harm, that human bring to animals and to present the consequences of exploitation to ecology, economy, people's health, moral and of course, to animals welfare. First of all, it was stated that in 2011 only for the sake of meat people killed more than 65.5 billion domestic farm animals, which is almost 8 times more than in 1961. Afterwards, it was mentioned that each egg is the result of 22 hours spent by hen in the A4 paper area drawer, whereas cows spend almost all their lifes in confinement and standing in one place in the stall, their calfs are taken away from them and they live 3-4 years instead of 25. Concerning clothes, people need to kill 350 squirrels to make one coat. In terms of economy, generally the problem of hunger was investigated and, for instance, people, in average, consume 19 billion liters a day and eat 10 billion kilograms of food, and one and a half billion cows drink 170 billion liters of water daily and eat 61 billion kilograms of food. It was shown that livestock is the main cause of greenhouse gases (19\%) and Amazon forest clearance (91\%).

Keywords: animals exploitation, vegan, vegetarian, animals sorrows, illness, ecology, economy.

\section{ИССЛЕДОВАНИЕ ЭКСПЛУАТАЦИИ ЖИВОТНЫХ В ИНДУСТРИЯХ ПРОИЗОДСТВА ПИЩИ, ОДЕЖДЫ, РАЗВЛЕЧЕНИЙ И ТЕСТИРОВАНИЯ. ВЛИЯНИЕ ЭКСПЛУАТАЦИИ НА ЭКОЛОГИЮ И МИРОВУЮ ЭКОНОМИКУ Ахметов P.P. (Российская Федерация)}

\author{
Ахметов Радмир Рустемович - студент, \\ кафедра транспорта и хранения нефти и газа, \\ Санкт-Петербургский горный университет, г. Санкт-Петербург
}

\begin{abstract}
Аннотация: в статье анализируются все сферы, в которых животные эксплуатируются человеком (пища, одежда, развлечения, тестирование), чтобь показать масштаб вреда и страданий, причиняемых животным, и последствий эксплуатации для экологии, экономики и здоровья человека. Для начала было показано, что в 2011 году только для мяса люди убили более 65 миллионов домашних животных, что в 8 раз больше, чем в 1961. Затем было указано, что каждое яйчо - это результат 22 часов, проведенных курицей в клетке размером с лист А4, погда как коровы проводят почти всю жизнь взаперти, стоя на одном месте, и их детей забирают у них после рождения. Живут такие коровы 3-4 года вместо 25. Касательно одежды, людям, например, нужно убить 350 белок, чтобы сделать одну шубу. Также была изучена проблема голода, связанная с эксплуатацией животных. Например, было показано, что 7 миллиардов человек в среднем потребляют 19 миллиардов литров воды и 10 миллиардов кг еды в день, тогда как 1,5 миллиарда коров в день выпивают 170 миллиардов воды и съедают 61 миллиард кг еды. В заключении было продемонстрировано, что скот - главная причина парниковых газов (19\%) и вырубки Амазонских лесов (91\%).
\end{abstract}

Ключевые слова: эксплуатация животных, веган, вегетарианеи, страдания животных, болезни, экология, экономика.

1. General Ethics

$98 \%$ of the total biomass - people and livestock, so there are less than $1 \%$ of predators. 65 billion animals and about 100 billion fish are killed every year by people only to eat meat. But predators kill according to need and instinct, and we kill unnecessary without need, create more deaths than necessary. Also predators do this because they can not reassure, they can not make another choice. For me, this nature, where one animal kills another is impossibly cruel too, but what people do with animals is worse than that.

Popular paintings of chickens and cows walking through the meadow and pigs swarming in the spacious puddles - this picture of the life of life does not reflect reality. The reality is that the life of these animals is filled with suffering, fear and stress, lack of space, the inability to move around, the lack of communication with relatives, the lack of fresh air and sunlight. Now from birth to death each meat-eater in developed countries eats about 3000 terrestrial and 3 thousand aquatic animals. In tables 1 and 2 is presented some data about the exploration of fish and animals to meet our demands $[1,2]$. 
Table 1. The number of animals killed only for meat in the world

\begin{tabular}{|l|l|l|l|l|}
\hline Year & Month & Day & Hour & Second \\
\hline 65665680429 & 5472140036 & 179905974 & 7496082 & 2082 \\
\hline
\end{tabular}

Table 2. The number of exploited living beings in the world

\begin{tabular}{|l|l|l|}
\hline Type & $\mathbf{1 9 6 1}$ & $\mathbf{2 0 1 1}$ \\
\hline Meat & 8.395 .460 .656 deaths & 65.665 .680 .429 deaths \\
\hline Fish & $17.719 .853 .012 \mathrm{~kg}$ & $148.522 .662 .915 \mathrm{~kg}$ \\
\hline Milk & 338.527 .436 cows & 660.280 .045 cows \\
\hline Eggs & 2.011 .456 .000 chicken & 6.925 .505 .121 chicken \\
\hline Clothes & 643.065 .162 deaths & 1.297 .408 .346 deaths \\
\hline
\end{tabular}

With fish everything is much more tragic. The fact is that there is such a thing as by-catch, that is not the target fish, which is not taken into account and is sometimes 95-99 percent. That is the statistics for fish, caught with a purpose, and everything else caught in the network is not taken into account, so you can at least double the amount to 300 billion $\mathrm{kg}$ and 200 billion fish.

According to the Institute of Demoscopy (IfD) and the Research Institute YouGov at the beginning of 2015 in Germany there were about 7.8 million vegetarians and 900 thousand vegans $(1.1 \%)[1,8]$.

3. Eggs and milk

In egg poultry farming there is no place for male chickens, and they are tortured to kill. To prevent chickens from injuring each other in endless fights, they are pruned by beaks. The beaks of the chickens are cut off and the shock often kills, but they still hurt.

Each egg is the result of 22 hours spent by a hen in a cage the size of a drawer, in one such cage sit 5 hens. The cells are piled one on top of another, those that stand higher fall on the lower ones. The area for one chicken is A4 paper size, they can not spread their wings better and go 2 steps.

Due to forced immobility, lameness develops in birds, and due to the constant deposition of eggs osteoporosis (all calcium goes to shell formation). Some birds die of hunger, because they can not reach the food. At the age of 2 years, the "egg reserve" of chickens is considered to be depleted, and they are sent to the slaughterhouse. And they would have lived to 4-5 years.

The cow spends all its life in confinement and standing in one place in the stall. In order for a cow to give milk, a calf must be born. It's nature that the calf, and not people, should drink cow's milk. But a day or two after birth, the calves are taken away from the cow, so that people drink milk. After the calf was born, cow gives milk for 10 months, then it is again inseminated, and the process repeats. So 4-5 years pass in constant pregnancies, painful childbirth.

In the natural setting, the average age of the cow would be 25 years. In modern conditions, they are sent to the slaughterhouse after 3-4 years of "work". Modern milk cow under the influence of intensive technologies produces 10 times more milk than in natural conditions [11].

When they are delivered to the executioners, some of them are pregnant, some still lactify (milk flows from the udder). Together with the blood on the floor of the massacre mother's milk flows, which her own calf never received.

Dairy cows are considered inanimate aggregates for the production of milk. They are treated without the slightest sympathy. Remorselessly used, the cow's body is depleted and surrenders. Cows are known as loving mothers who protect their babies. Everyone who has ever lived on a dairy farm and heard the heartbreaking cries of the mother-cow, who has been taken away from the child, knows that she feels deeply depressed. Her suffering can last for weeks, until, broken, she finally does not lose the hope of finding her lost child. The loss of a baby is terrible; And it's probably better that the cow mother can not see him inside a dark pen, frightened and lonely, condemned to such a fate by cruel, self-centered people. No mother and no child should experience such horrors.

Veal is one of the most cruel forms of violence against animals, especially because the victim is a newborn, who, having just stepped into this world, is immediately taken away from the mother and never sees her again. At first the calf is small and can still turn inside the stall - that's why it is tied to the stall by the neck - to prevent it from moving and developing muscles [9]. 
4. Clothes, alcohol, tobacco, cosmetics and entertainment

Beauty can not be cruel. For the slaughter of fur animals, the most cruel methods are used. For example, the passage of current through the anus or genitals. Being in full consciousness, the animals die from a heart attack. Other methods of slaughter include poisoning with gas, injecting poison and paralyzing substances, asphyxiation. Sometimes animals are slightly deafened, and with the still alive rip off skins. Karakul is lambs killed on the 2-3 day after birth. People need to kill 350 squirrels, 170 chinchillas, 140 ermines, 70 sables, 60 martens and 60 mink to make 1 natural coat. To get the skin, you need to kill the cow. Almost half of the animals die before delivery to the slaughterhouse, the cows are killed before each other, instead of cutting their throats with a knife they are usually killed by cutting or sawing with a blunt blade.

Here is some statistics about exploitation of animals in alcohol, tobacco and cosmetics industry (Figure 1). In some countries, for example, in Germany, the law prohibits the addition of any animal ingredients [10].
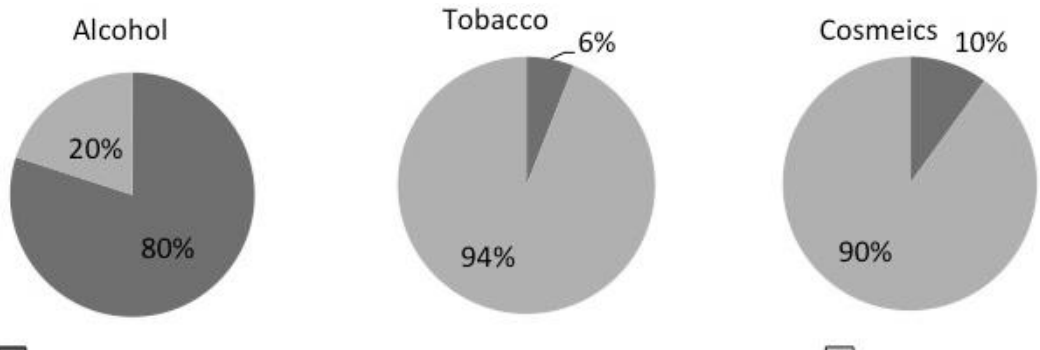

- Not tested on animals and do not include animal products

$$
\text { - others }
$$

Fig. 1. Chart of different products tested on animals

Dolphins are tortured to perform tricks. They are kept in pools of small space, they experience wild stress and are covered with ulcers Life expectancy of dolphins is reduced by four times. It's an illusion that they always smile, even when they're doing tricks. In a wild nature they behave differently. They swim at an hour 25 miles in the wild. Thousands of dolphins are killed in small towns throughout Japan.

Talking about zoos. The preservation of the animal world on the planet will be facilitated primarily by the prohibition of the ruthless extermination of animals by hunters, trapping and their use for practical purposes by mankind, one of which is the maintenance of zoos. The only thing that zoos teach is to accept and ignore the basic needs of animals. Indeed, what can we say about animals, observing them in confinement, and not in living nature. Zoos exist solely because we love exotic things. Visitors perceive animals only as things.

There is a notion that in entertainment we provide animals with a good life and maintain a view in exchange for entertainment, although in reality in most cases (not always) is the exchange of animal suffering for people's entertainment. In some circuses nowadays the methods of training with a minimum of damage are gradually introduced, but in the overwhelming majority of cases, the animals do not stand up for the reward, but because they are afraid of punishment. They live in isolated empty cells without communication with relatives. At best, they are simply beaten with sticks and electrocuted, but all this is certainly only outside the arena, during the performance, people see only the performance of the stunt of an unhappy, frightened animal.

Concerning fishing and hunting, fish have a complex nervous system, one of the functions of which is sending a signal about pain in the brain. This is part of the survival mechanism, without which fish could not exist. The same is for animals. Hunters kill around 250 million animals every year in the US [11].

5. Medical vivisection

The disease is artificially caused in animal, then the so-called LD50 test is performed, this test increases the dosage of the effective drug until half of the animals die - and so determine the effective dosage. Usually 8-10 mice are taken. The reliability of such experiments is about 95 percent - this argument is actively used by opponents of vivisection, since less than 5 percent is due to possible errors due to the different effects of certain substances on the animal and human organism.

There are generally 2 types of drug testing in vitro - not on live animals, but on cells. For example, take blood or smear from an animal or a person. Another way - in vivo - on animals. The crucial fact is that now the gradual transition from in vitro to in vivo begins due to simplicity and reliability. So for example, in 1980,190 million animals were tested, and in 2015 there are only 120 million [10]. 


\begin{tabular}{|c|c|c|c|c|}
\hline \multicolumn{2}{|c|}{ The Use of Vivisection: } & \multicolumn{3}{|c|}{ Test of medicines: } \\
\hline \multirow{4}{*}{\multicolumn{2}{|c|}{$\begin{array}{l}\text { - Medications } \\
\text { - The course of the disease } \\
\text { - Study of the structure of the body } \\
\text { - Military research } \\
\text { - Sport research } \\
\text { - Education }\end{array}$}} & \multicolumn{2}{|c|}{$\begin{array}{l}2 \text { factors: } \\
\text { Process: }\end{array}$} & $\begin{array}{l}\text { - Effectiveness of the drug } \\
\text { - Dosage }\end{array}$ \\
\hline & & Step 1 & \multicolumn{2}{|c|}{ We cause disease in 10 mice } \\
\hline & & Step 2 & \multicolumn{2}{|c|}{ Increase the dose to LD50 } \\
\hline & & Step 3 & \multicolumn{2}{|c|}{ Determine the effectiveness and dosage } \\
\hline \multirow{5}{*}{$\begin{array}{l}\text { Reliability of } \\
\text { Vivisection, \% }\end{array}$} & \multirow{5}{*}{$\begin{array}{l}\text { Use of Mice, } \\
\text { rats, \% }\end{array}$} & \multicolumn{2}{|c|}{ In vitro } & In vivo \\
\hline & & \multicolumn{2}{|c|}{ Test on cells, tissues, etc. } & Tests on animals \\
\hline & & \multicolumn{3}{|c|}{ simplicity, reliability } \\
\hline & & \multicolumn{2}{|r|}{1980 year } & 2015 year \\
\hline & & \multicolumn{2}{|r|}{ Around $190 \mathrm{~m}$} & Around $120 \mathrm{~m}$ \\
\hline
\end{tabular}

Fig. 2. Vivisection scheme

6. Economy

Of course, the problem of hunger will not be solved by veganism, but it can be made easier for the following reasons: Mankind consumes 19 billion liters a day and eats 10 billion kilograms of food, and one and a half billion cows alone (just as many cows now on the ground) drink 170 billion liters of water daily and eat 61 billion kilograms of food.

Producing 1 kilogram of meat requires 16 kilograms of cereals and legumes. To produce $1 \mathrm{~kg}$ of bread, $1 \mathrm{~kg}$ of grain is needed (Figures 3, 4).

$20 \%$ of corn, grown in the US, is consumed by people. $80 \%$ of corn, grown in the US, goes to feed livestock. $95 \%$ of the oats grown in the US go to livestock feed. $90 \%$ of protein is lost when digesting grains by livestock. $99 \%$ of carbohydrates - by digesting grains by livestock. To produce an egg, 38 components are needed to 1 , for eggs from plant components 2 to 1 . For soy or rice milk, you need 20 times less land than for milk from cows [7, $8]$.

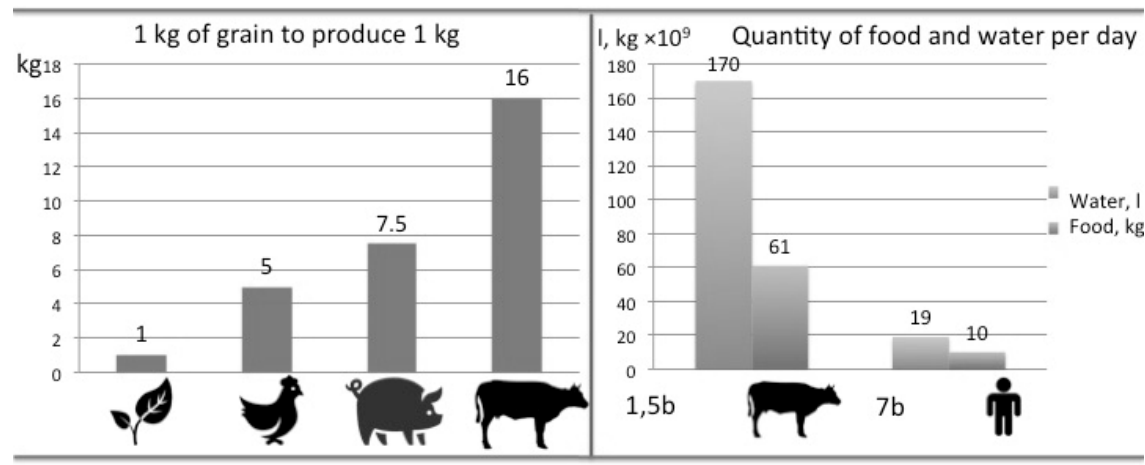

Fig. 3. Food and water expenses to plant and livestock products

\section{Allocated for livestock, \%}
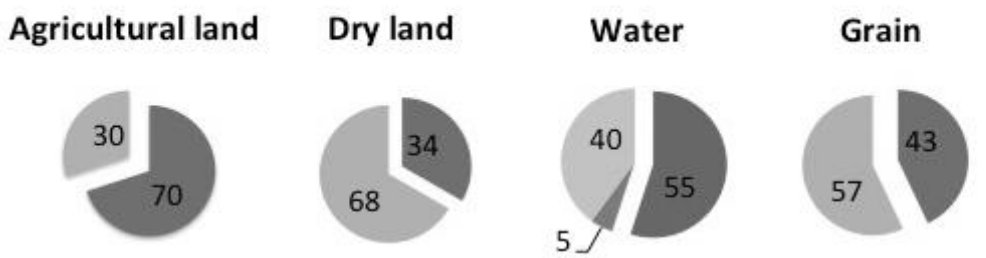

Fig. 4. Percentage of areas allocated for livestock

7. Ecology and health

The presence of greenhouse gases in the atmosphere is the reason the climate becoming more humid, sea level rises. It is also the threat to ecosystems and biological diversity, glaciers melt, affects water consumption and water supply. And the Amazonian forests are one of the main ecological systems in the world. Here is the statistics of the influence of livestock breeding on greenhouse gases and cutting of Amazonian forests (Figure 5). 
Talking about health, The American Dietetic Association confirms that vegetarian diets, including vegan diets (with basic control over the level of certain substances, for example, vitamin B-12) are suitable for people of any age and any period of life, including pregnancy and lactation, and also help in the prevention and treatment of some Diseases. For example, such as diabetes and cancer. The next table presents nutrients essential to control $[1,3]$.

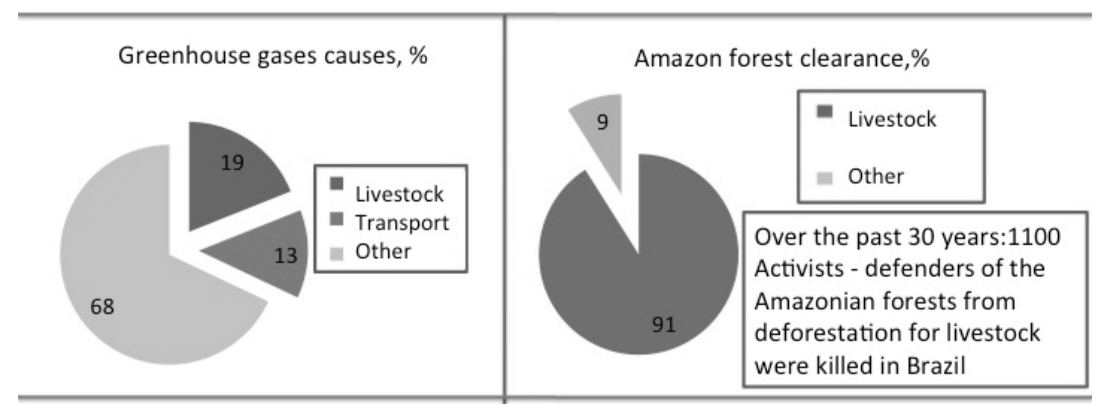

Fig. 5. Influence of livestock on greenhouse gases and Amazon deforestation

\section{References / Список литературы}

1. Food and agriculture organization of the United Nations reports, 2013, 2014.

2. Fox N., Ward K. Health, ethics and environment: a qualitative study of vegetarian motivations. Appetite, 2008;50:422-9.

3. Rollin B.E. Farm animal welfare: social, bioethical, and research issues. Ames I.A: Wiley-Blackwell, 2003.

4. Tuttle W. The World Peace Diet. Iantern, 2004.

5. Ellefse R., Sollund R. and Larsen. G., 2012. Eco-global crimes. Contemporary problems and future challenges. Farnham: Ashgate.

6. United nations report. 29 November, 2006.

7. White R., 2008. Crimes Against Nature: Environmental Criminology and Ecological Justice. Willan Publishing, Devon.

8. Singer P.. 1975. Animal liberation. New York: New York review.

9. Nurse A., 2013. Animal harm. Perspectives on why people harm and kill animals. Farnham, Surrey: Ashgate.

10. Nibert D., 2002. Animal rights Human rights. Entanglements of oppression and liberation. Lantham: Rowman and Littlefield.

11. Flynn C., 2011. Examining the links between animal abuse and human violence. Crime, law and social change 55:455-468. 